ELORE (ISSN 1456-3010), vol. 19 - 2/2012.

Julkaisija: Suomen Kansantietouden Tutkijain Seura ry.

[http://www.elore.fi/arkisto/2_12/lofgren.pdf]

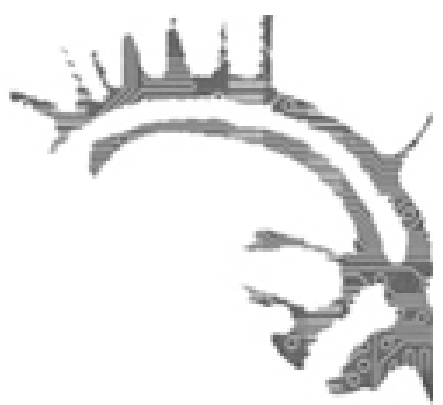

\title{
AktuelLt
}

\section{FOLKLORE AND FANTASY}

\author{
Jakob Löfgren
}

Konferens anordnad av Folklore Society's och Sussex Centre for Folklore, Fairytales and Fantasy vid University of Chichester den 13-15 april 2012.

Den 13:e till 15:e april 2012 anordnade The Folklore Society och Sussex Centre for Folklore, Fairytales and Fantasy en gemensam konferens på temat "Folklore \& Fantasy". Konferensen hölls på Chichester University där Sussex Centre for Folklore, Fairytales and Fantasy håller till. Jag hade turen att bli utvald att presentera min egen forskning kring fantasy-fans och folklore på denna konferens och kunde delta med finansiell hjälp från Svenska litteratursällskapet. Temat "Folklore \& Fantasy" visade sig vara efterfrågat och samlade folklorister från hela världen som i två dagar diskuterade och debatterade de intertextuella kopplingarna mellan folklore och fantasy-litteratur. Bland annat deltog folklorister från olika delar av Storbritannien, Japan, Nederländerna och Ryssland. Då temat för konferensen var så populärt var den uppdelad i flera parallella sessioner. Jag kommer här att redogöra för en del av de föredrag jag hann gå på.

\section{AKADEMIKER OCH INTERTEXT}

En konferens är ju först och främst en plattform för diskussion och utbyte av idéer och det ska sägas att föredragshållarna på denna konferens kom från ett bredare spektrum än vad 
jag har varit van vid då jag deltagit i konferenser här hemma, det vill säga att det här deltog folk med vitt skilda intressen för folklore och fantasylitteratur. Det medverkade förstås en hel del akademiska folklorister, men också författare och andra intresserade. Som forskare med ett intresse för intertext var detta väldigt intressant. Eftersom deltagarna kom från en bredare kontext så representerade också anförandena skilda infallsvinklar på kopplingen mellan folklore och fantasy.

Bland de mera akademiskt inriktade anförandena kan nämnas ett mycket intressant föredrag av Karen Graham, forskarstuderande vid University of Aberdeen, som talade om re-appropriation av myter i Gregory Maguires fiktion. PhD Helen Sutherland (University of Glasgow) höll också ett fängslande tal på ett liknande tema. Det handlade om hur folklore används som historiska fakta i Sylvia Townsend Warners fiktion, eller hur man kan använda folklore som ett medel för att ge fiktion en "annan historia". Ett riktigt intressant föredrag hölls också av Tina Paphitis, forskarstuderande i arkeologi vid University College London om förhållandet mellan arkeologi och kulturerna i J. R. R. Tolkiens trilogi. Paphitis anförande visade på hur folklore påverkat den brittiska arkeologin och hur sedan den brittiska arkeologin påverkat J. R. R. Tolkien i sin framställning av området Barrow Downs i trilogin om härskarringen.

\section{INTERTEXT SOM PRAKTISKT ARBETSREDSKAP}

De riktigt stora ögonöppnarna kom från föredragshållare som hade en lite annan vinkel än den folkloristiska eller en annan syn på intertext än jag själv. Bland sådana föredragshållare vill jag särskilt nämna två stycken: Anthony Nanson och Kate Forsyth. Anthony Nanson är lärare i kreativt skrivande vid Bath Spa University och Kate Forsyth är fantasyförfattare från Australien. Det som jag tog med mig från båda föredragshållarna var en ny förståelse om hur intertextualitet används som arbetsredskap i deras respektive arbeten.

Anthony Nanson har gett ut flera samlingar av engelska folksagor och talade om hur han använder sig av sin kännedom om folksagans konstruktion då han presenterar folksagor i skriven form. Nansons föredrag visade på ett handgripligt sätt hur folksagan förändras då den ska anpassas till kommersiella sammanhang. Bland annat så talade Nanson om hur han hittat intressanta men fragmentariska nerteckningar av sagor i arkiv. Nanson menade att han, i sådana fall, litat på sin egen kunskap om folksagans struktur och teman och "fyllt i" det som fattats för att göra en mer intressant och hel saga. Som finsk folklorist var det intressant att se att moderna utgivare av folksagor fortfarande arbetar lite som Lönnrot, som också "fyllde i" för att bilda en mer logisk helhet i Kalevala (jämför Honko 1980:38). När han hittar fragment av en saga som han anser vara intressant letar han sedan efter liknande teman och andra sagor $i$ andra delar av Storbritannien och Europa och utifrån detta pusslar han ihop en ny variant av fragmenten. Nanson talade öppet om hur han själv konstruerar nya varianter av engelska folksagor, helt medveten om att folkloren som form karaktäriseras av variantbildning. Det var fascinerande att höra att han ser böckerna som han ger ut som en förlängning av folksagotraditionen.

Jag har tidigare i olika sammanhang träffat fantasyförfattare men under Chichester- 
konferensen hade jag turen att få höra på ett anförande av den australiensiska författaren Kate Forsyth. Något som jag anser ofta har försummats i forskningen kring intertext och intertextualitet är det praktiska användningsområdet av intertext. Forsyth talade främst om användningen av skotsk folklore i hennes bok The Puzzle Ring (2009) och omskrivningen av Rapunsel i hennes verk Bitter Green (2012). Det är sällan man får höra hela processen bakom en författares val att inspireras av folksagor. I fallet Bitter Green så förklarade Forsyth att hennes efterforskning tagit henne från sagan till den första litterära varianten av den och hur de båda möts och stått som inspirationskälla till Forsyths egen variant. Både Forsyths och Nansons föredrag fick mig att fundera på intertextualitetsbegreppet och hur brett ett sådant begrepp är. Att få höra hur detta går till i praktiken kommer förstås att påverka hur jag ser på begreppet och i förlängningen kan det också påverka mitt eget arbete. En del av föredragshållarna på denna konferens diskuterade fantasi och fantasy ur ett annat perspektiv. Jag vill framförallt lyfta fram Marc Armitage som arbetar med barnlekvärlden. Armitage höll ett mycket underhållande föredrag om de fantastiska och folkloristiska inslagen i leken på skolgårdar världen över. Som exempel lyfte han fram "spöket på toaletten" som i hans empiriska forskning är ett återkommande fenomen i 90\% av skolorna världen över (Storbritannien, Japan, Ungern, Sverige). Detta tema finns även återgivet i J. K. Rowlings böcker om Harry Potter i karaktären Moaning Myrtle.

\section{SAGOBERÄTTARE OCH FOLKLORENS POPULARITET I STORBRITANNIEN}

Något som slog mig när jag besökte denna konferens var skillnaden i populariteten av folklore och folkloristik mellan Storbritannien och Finland. Folklore Society och Sussex Centre for Folklore, Fairytales and Fantasy har lyckats med något som jag anser att vi inte har gjort (i alla fall inte i samma grad) med våra egna konferenser här hemma. I Finland är särskilda genrer populära, så som exempelvis folkdans. Folkdansutövare kommer på akademiska konferenser som berör just genren folkdans. I Storbritannien finns det en publik som aktivt söker och sysslar med folklore som hobby. Ett exempel på detta är att en liten grupp från Essex som besökte konferensen hade folkloristiskt insamlingsarbete som hobby. De besökte konferensen i syfte att träffa och lyssna till de akademiska folkloristernas akademiska föredrag. Skillnaden är den att människor som har detta som hobby i Storbritannien ofta (som jag har förstått det) också har folkloristik som hobby. Dessa "hobbyfolklorister" kallas ofta för "folkies". Att konferensen hade deltagare utanför de akademiska kretsarna visar på att folkloristik har en annan grad av popularitet i Storbritannien än i Finland. Med detta menar jag att det syns ett större publikt intresse för folkloristisk forskning i Storbritannien än här hemma.

Konferensen besöktes också av flera professionella sagoberättare. En av dessa, som är väldigt aktiv i Sussex Centre for Folklore, Fairytales and Fantasy, Janet Dowling höll ett föredrag om The Green man. Dowling redogjorde för hur hon berättar om karaktären The Green man, som är en folklig bild av Bibelns Adam, då hon gör guidade turer i olika 
kyrkor i Storbritannien. Föredraget var mycket intressant eftersom det belyste hur en modern berättare talar om och förmedlar folksägner och sagor i dagens värld. I diskussionen efteråt talades det om vad man tidigare utelämnat ur de traditionella varianterna och hur man i dag väljer att gå till nertecknade källor för att få en så "autentisk" variant som möjligt. Än en gång väcktes diskussionen om intertext som arbetsredskap för moderna berättare. De sagoberättare som var på plats hade även sessioner där de berättade olika engelska folksagor. Andra engelska folkloreutövare var också på plats. Bland annat gav sånggruppen The Hares and South Downs Singers en konsert i samband med konferensen.

Personligen såg jag nytta i att det fanns allt från akademiska folklorister, till författare, professionella sagoberättare och annars bara intresserade personer på konferensen $\mathrm{i}$ Chichester. Här tycker jag att Finland har en del att lära av britterna. Om man anser att konferensens syfte är att utbyta idéer om ett visst ämne tror jag att det ligger en nytta i att få ett så brett spektrum av idéer som möjligt. Detta kan enligt min åsikt endast gynna forskningsarbetet. Förstås ska man inte heller glömma bort vikten av att ens forskningsarbete också kan intressera folk utanför den rent akademiska kontexten.

\section{NYA FÖRBÄTTRADE KONTAKTER TILL STORBRITANNIEN}

"Socialt nätverkande" är ett fenomen som har vunnit popularitet under de senaste åren. Om jag ska lyfta fram något nyttigt som jag tagit med mig från att åka på konferens är det de kontakter jag gjort. Framförallt vill jag lyfta fram Sussex Centre for Folklore, Fairytale and Fantasy, som ett potentiellt viktigt center, särskilt för forskare som studerar folklore och intertextualitet. Jag vill också nämna att det från detta center, från och med maj 2012, ges ut en ny tidsskrift för artiklar kring kopplingen mellan fantasylitteratur och folklore. Tidskriften heter Gramarye.

Till sist vill jag lyfta fram en underlig sak som jag fick frågor om under konferensens gång. Varför är inte samarbetet mellan Finland och Storbritannien mer utvecklat? Det slog mig att jag under mina studieår vid Åbo Akademi rest Europa runt på fältarbeten av alla de slag, men i folkloristiskt/akademiskt syfte besökte jag England först i samband med mitt eget forskningsarbete. Om man väger in det faktum att en stor del av det populärkulturella utbudet och utbytet idag kommer just från Storbritannien blir frågan ännu viktigare. Inom musiken kan man ju bara nämna Beatles och Rolling Stones, Black Sabbath och Iron Maiden och från TV:ns värld kan nämnas allt från Doctor Who till Downton Abbey och Monty Python. Jag fick under konferensens gång på gång frågan: "Varför ser vi inte fler finländska föredragshållare på Folklore Society’s konferenser?" Jag konfronterades även med min egen okunskap om den engelska folkloren och alla dess uttryck, allt från Morris Dance till folksägner diskuterades. Jag är glad att jag fick chansen att bekanta mig med experter på den engelska folkloren, dels för min egen kunskap, men även på grund av att mitt eget forskningsområde är beroende av en förståelse av "det engelska”. Det ska ändå påpekas att det från olika deltagare på konferensen framfördes en önskan om ett djupare samarbete våra länder emellan, något som jag själv vill uttrycka mitt stöd för. 
Summan av mitt eget besök på denna konferens kan sägas bestå i dels ett nyttigt utbyte av tankar och idéer, dels i de sociala kontakterna jag skapat och slutligen i min egen ökade förståelse för studierna av och populariteten kring folklore i Storbritannien. Jag tror att vi kan lära oss något av och dra nytta av idéer kring popularisering från Storbritannien. Dessutom hoppas jag att genom denna rapport uppmanat finländska folklorister till ett ökat utbyte med Storbritannien.

\section{LITTERATUR}

HONKO, LAURI 1980: Upptäckten av folkdiktning och nationell identitet i Fin-

land. - Honko, Lauri (red.), Folklore och nationsbyggande i Norden. Åbo: Nordiska institutet för folkdiktning.

FORSYTH, KATE 2009: The Puzzle Ring. Pan Macmillan: Sydney

FORSYTH, KATE 2012: Bitter Green. Random House Books: Sydney

Filosofie magister Jakob Löfgren är doktorand och universitetslärare i Nordisk folkloristik vid Åbo Akademi. 